\title{
用途別着工建築物工事費予定額の短期変動について
}

一一季節変動を中心として—

正会員島田良 一*

1. 序

用途別の着工建筑物工事費予定額の短期变動の分析と して，季節変動パターンとその有意性，不規則変動の大 きさ等について若干の考察を試みる（註1)。資料は建設 省計画局，建築動態統計月報により，用途別の着工予定 額の月別推移をもちいた（註 2)。季節要素の抽出は対移
動平均比法によるものとし，計算手続の大筋は米国セン サス局法 II・X 11 にしたがった（补3）。

建築動態統計における「用途別」分類は, Table. 1,2, 3 の分類にみるとおり，建物の使用目的による建物種類 別と，建物使用者の産業分類別との組みあわせにより規 定されておうり，いちおう「主体別」分類とは独立である

Table. 1 Some extracts from variance analysis table for testing the stable seasonality of building starts by use and by industries (major group). 1953-67 $\mathrm{F}_{120}^{10}(0.01)=2.47$

\begin{tabular}{|c|c|c|c|c|c|c|c|c|c|c|}
\hline & & \multicolumn{3}{|c|}{ Sum of Squares } & \multirow{2}{*}{$\mathbf{F}$} & \multicolumn{2}{|c|}{ Standard Deviation } & \multirow{2}{*}{$A(64.1)$} & \multirow{2}{*}{$\sigma_{T} \mathrm{~A}$} & \multirow{2}{*}{$\sigma_{R} \mathrm{~A}$} \\
\hline & & Total & $\begin{array}{r}\text { Between } \\
\text { months }\end{array}$ & Residuals & & $\sigma_{\boldsymbol{T}}$ & $\sigma_{R}$ & & & \\
\hline Exclusively for dwelling & 居住専用建筑物 & 2.66 & 1.49 & 1.17 & 19.57 & 0.122 & 0.083 & 50,511 & 6,157 & 4,208 \\
\hline Dwelling industry concurrent use & 居住䈐業併用建築物 X & 3.56 & 2.58 & 0.99 & 39.84 & 0.141 & 0.077 & 13,796 & 1,947 & 1,058 \\
\hline Agriculture forestry and fishery & 軙林水座業用建築物 F & 5.77 & 2.33 & 3.44 & 10.37 & 0.180 & 0.143 & 1,923 & 345 & 275 \\
\hline Mining and manufacturing & 鉝工業用建築物 N & 3.89 & 1.00 & 2.38 & 6.41 & 0.140 & 0.119 & 23,114 & 3,178 & 2,753 \\
\hline Commercial & 商業用建筑物 & 12.72 & 1.11 & 11.61 & 1.46 & 0.267 & 0.263 & 15,535 & 4,142 & 4,084 \\
\hline Public utility & 公益事業用建筑物 & 13.29 & 1,46 & 16.84 & 1.32 & 0.320 & 0.317 & 5,609 & 1,793 & 1,776 \\
\hline Service & サービス業用建築物 S & 7.81 & 1.45 & 6.35 & 3.49 & 0.209 & 0.195 & 10,404 & 2,172 & 2,024 \\
\hline Official and educational & 公務文数用建築物 O & 8.51 & 3.61 & 4.90 & 11.24 & 0.218 & 0.171 & 15,809 & 3,446 & 2,700 \\
\hline Others & 他に分類されない建築物 & 63.82 & 9.71 & 54.12 & 2.74 & 0.598 & 0.568 & 195 & 116 & 111 \\
\hline
\end{tabular}

Table. 2 Some extracts from variance analysis table for testing the stable seasonality of building starts by use and by industries (Intermediate group) 1960-67 $\mathrm{F}_{\mathrm{B} \text { 4 }}(0.01)=2.42$

\begin{tabular}{|c|c|c|c|c|c|c|c|c|c|c|}
\hline & \multicolumn{3}{|c|}{ Sum of Squares } & \multirow{2}{*}{$\mathbf{F}$} & \multicolumn{2}{|c|}{ Standard Deviation } & \multirow{2}{*}{$A(64.1)$} & \multirow{2}{*}{$\sigma_{T} \mathrm{~A}$} & \multirow{2}{*}{${ }^{o} R \mathrm{~A}$} \\
\hline & & Total & $\begin{array}{c}\text { Between } \\
\text { months }\end{array}$ & Residuals & & ${ }^{\sigma} T$ & $\sigma_{R}$ & & & \\
\hline Ordinary dwelling & 居住專用住宅 D 1 & 2.30 & 1.67 & 0.63 & 23.17 & 0.147 & 0.081 & 49,151 & 7,210 & 3,98 \\
\hline $\begin{array}{l}\text { Quasi-dwelling (Dormitory and } \\
\text { others) }\end{array}$ & 居住専用滥住宅 D 2 & 5.25 & 3.69 & 1.56 & 20.64 & 0.221 & 0.127 & 6,410 & 1,419 & 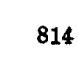 \\
\hline $\begin{array}{l}\text { Dwelling, and agriculture, foresty } \\
\text { or fishery }\end{array}$ & 居住農林水産菜 $X_{1}$ & 5.88 & 4.98 & 0.89 & 48.74 & 0.234 & 0.096 & 1,181 & 277 & \\
\hline $\begin{array}{l}\text { Dwelling, and mining or manufa- } \\
\text { cturing }\end{array}$ & 居住鉱工業併用 $\mathrm{X} 2$ & 2.29 & 1.21 & 1.07 & 9.87 & 0.146 & 0.106 & 1,838 & 269 & \\
\hline Dwelling and commercial & 居住商業併用 X3 & 2.44 & 1.92 & 0.52 & 32.00 & 0.156 & 0.074 & 8,597 & 1,341 & 63 \\
\hline Dwelling and service & 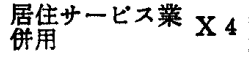 & 3.51 & 1.34 & 2.17 & 14.08 & 0.186 & 0.150 & 1,482 & 276 & \\
\hline \multicolumn{11}{|l|}{ Buildings for } \\
\hline Coal Mining & 石炭鉱業用 $\mathrm{M} 1$ & 48.52 & 10.70 & 37.83 & 2.47 & 0.67 & 0.63 & 49 & 33 & \\
\hline Other mining & 鉱 業 用 M 2 & 32.40 & 5.07 & 27.32 & 1.62 & 0.55 & 0.53 & 110 & 61 & \\
\hline Construction & 建 設業 用 M3 & 14.25 & 2.13 & 12.12 & 1.53 & 0.36 & 0.36 & 1,153 & 421 & 409 \\
\hline Food and Kindred pr & 食料品製造業用 M4 & 8.37 & 1.37 & 7.00 & 1.71 & 0.28 & 0.27 & 2,395 & 670 & 647 \\
\hline Textile & 織維工業用 M5 & 5.49 & 0.59 & 4.90 & 1.05 & 0.23 & 0.23 & 1,888 & 428 & 427 \\
\hline Lumber and $w$ & 木紫品浩業用 M6 & 4.08 & 1.09 & 2.99 & 3.18 & 0.20 & 0.18 & 922 & 180 & 16 \\
\hline $\begin{array}{l}\text { Pulp, paper and finished allied } \\
\text { products }\end{array}$ & 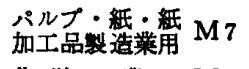 & 2 & 1.82 & 1 & 9 & 3 & 0.32 & 783 & 260 & 25 \\
\hline Chemical and related industrics & 化学工業用 M8 & 11 & 2.45 & 78 & 2.43 & 0.32 & 0.30 & 2,436 & 789 & 73 \\
\hline Petroleum a & 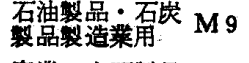 & 25.22 & 4.05 & 21.17 & 1.67 & 0.49 & 0.47 & 274 & 133 & 12 \\
\hline $\begin{array}{l}\text { Stone, clay, glass and pottery } \\
\text { products }\end{array}$ & 䆭業，造業不製品 N 1 & 9.44 & 2.57 & 6.87 & 3.27 & .30 & .27 & 759 & 225 & 20 \\
\hline Iron and steel industry & 鉄鍽業用 $\mathrm{N2}$ & 9.00 & 1.84 & 7.17 & 2.24 & 0.29 & 0.27 & 2,534 & 735 & 69 \\
\hline
\end{tabular}

* 東京都立大学工学部助手

(昭和 43 年 9 月 14 日本稿受理, 封䀫期限昭和 44 年 7 月末日)

（注 1）本稿は手法的にも内容的にも文献 (5)および (6) に 接続するものであり，本稿全般にわたり，とくに文献 (5) の参
照を必要とする。

（注 2）資料の問題点については文献 (1), (2)，(5) を参照。 （注 3）本稿の分析手法については文献(5)，センサス局法に ついては文献 (3), (4)を参照。他に EPA 法, MITI 法がある。 


\begin{tabular}{|c|c|c|c|c|c|c|c|c|c|c|}
\hline & & \multicolumn{3}{|c|}{ Sum of Squares } & \multirow{2}{*}{ F } & \multicolumn{2}{|c|}{ Standard Deviation } & \multirow{2}{*}{$A(64.1)$} & \multirow{2}{*}{$\sigma_{T} \mathrm{~A}$} & \multirow[b]{2}{*}{$\sigma_{R} \mathbf{A}$} \\
\hline & & Total & $\begin{array}{r}\text { Between } \\
\text { months }\end{array}$ & Residuals & & ${ }^{\sigma_{T}}$ & ${ }^{\sigma_{R}}$ & & & \\
\hline Non-ferrous metal industry & 韭铁金属跤造業 N 3 & 26.83 & 3.23 & 23.60 & 1.19 & 0.50 & 0.50 & 301 & 151 & 149 \\
\hline Fabricated metal produsts & 金属製品製造業 N 4 & 5.63 & 0.36 & 5.27 & 0.60 & 0.23 & 0.23 & 1,628 & 373 & 381 \\
\hline $\begin{array}{l}\text { Electrical machinery equipment } \\
\text { and supplies }\end{array}$ & 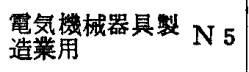 & 12.70 & 1.61 & 11.10 & 1.26 & 0.34 & 0.34 & 1,558 & 537 & 530 \\
\hline Transportation equipment & 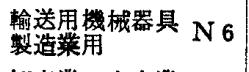 & 10.50 & 0.55 & 9.95 & 0.48 & 0.31 & 0.32 & 1,831 & 574 & 590 \\
\hline Whole sale and retail trade & 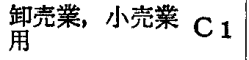 & 5.37 & 0.38 & 4.99 & 0.68 & 0.22 & 0.23 & 7,120 & 1,596 & 1,623 \\
\hline Restrant & 飲食店 用 $\mathrm{C}_{2}$ & 11.80 & 4.49 & 7.31 & 5.36 & 0.33 & 0.28 & 602 & 200 & 166 \\
\hline Finance, insurance and real estate & 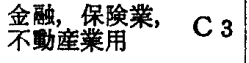 & 19.07 & 4.48 & 14.58 & 2.68 & 0.44 & 0.39 & 10,174 & 4,294 & 3,968 \\
\hline Transportation and warehousing & 運 輸 業 用 P 1 & 7.74 & 0.49 & 7.25 & 0.58 & 0.27 & 0.28 & 2,772 & 745 & 762 \\
\hline Communication & 通 信 業 用 $\mathrm{P} 2$ & 30.17 & 3.78 & 26.39 & 1.25 & 0.53 & 0.52 & 1,782 & 946 & 940 \\
\hline Electricity & 氜気業用 $\mathrm{P}_{3}$ & 54.57 & 7.47 & 44.10 & 1.38 & 0.71 & 0.68 & 780 & 557 & 529 \\
\hline Gas & カ ス業用 P 4 & 56.16 & 8.64 & 47.53 & 1.59 & 0.72 & 0.70 & 89 & 64 & 62 \\
\hline Water & 水道莱 用 P 5 & 79.29 & 11.09 & 68.20 & 1.42 & 0.86 & 0.84 & 159 & 137 & 134 \\
\hline Hotels and other lodgings & 宿 泊 業 用 S 1 & 14.34 & 4.40 & 9.95 & 3.86 & 0.37 & 0.32 & 4,128 & 1,511 & 1,329 \\
\hline $\begin{array}{l}\text { Amusement and recreation } \\
\text { services }\end{array}$ & 娛楽業 用 S 2 & 17.59 & 4.47 & 13.12 & 2.97 & 0.41 & 0.37 & 1,397 & 566 & 517 \\
\hline Medical and other health services & 医 爒 業 用 S 3 & 5.46 & 0.90 & 4.56 & 1.73 & 0.23 & 0.22 & 3,365 & 760 & 733 \\
\hline Government & 公 拐 用 $\mathrm{O}_{1}$ & 9.76 & 2.49 & 7.27 & 2.99 & 0.302 & 0.275 & 3,526 & 1,065 & 970 \\
\hline Non-protit organization & 非営利的団体用 $\mathrm{O}_{2}$ & 9.46 & 1.45 & 8.02 & 1.58 & 0.297 & 0.289 & 2,135 & 635 & 617 \\
\hline Education & 教 用 $\mathrm{O} 3$ & 11.59 & 9.52 & 2.07 & 40.12 & 0.329 & 0.147 & 11,782 & 3,877 & 1,732 \\
\hline Religion & 用 $\mathrm{O}_{4}$ & 11.74 & 3.76 & 7.98 & 4.12 & 0.331 & 0.288 & 716 & 237 & 206 \\
\hline
\end{tabular}

Table. 3 Some extracts from variance analysis table for testing the stable seasonality of building starts by use $1960-67 \mathrm{~F}_{\mathrm{B4}}^{11}(0.01)=2.42$

\begin{tabular}{|c|c|c|c|c|c|c|c|c|c|c|}
\hline & & \multicolumn{3}{|c|}{ Sum of Squares } & \multirow{2}{*}{$\mathbf{F}$} & \multicolumn{2}{|c|}{ Standard Deviation } & \multirow{2}{*}{$\mathrm{A}(64.1)$} & \multirow{2}{*}{${ }^{\sigma}{ }_{T} \mathrm{~A}$} & \multirow{2}{*}{$\sigma_{R} \mathrm{~A}$} \\
\hline & & Total & $\begin{array}{r}\text { Between } \\
\text { months }\end{array}$ & Residuals & & ${ }^{\circ} \boldsymbol{T}$ & $\sigma_{R}$ & & & \\
\hline Office & 事 㘯 & 6.69 & 1.02 & 5.66 & 1.57 & 0.250 & 0.243 & 21,191 & 5,300 & 5,145 \\
\hline Shop & 店赤 & 8.98 & 1.65 & 7.33 & 1.96 & 0.290 & 0.296 & 3,545 & 1,027 & 1,050 \\
\hline Factory & 工場及び作業場 & 1.86 & 0.60 & 1.25 & 4.21 & 0.132 & 0.114 & 17,862 & 2,354 & 2,042 \\
\hline Warehouse & 倉暷 & 1.88 & 0.41 & 1.47 & 2.43 & 0.132 & 0.124 & 6,145 & 814 & 760 \\
\hline School & 学校の校舍 & 13.22 & 10.73 & 2.49 & 37.63 & 0.352 & 0.161 & 10,916 & 3,837 & 1,757 \\
\hline Hospital & 病院・彭療所 & 8.26 & 0.71 & 7.54 & 0.83 & 0.278 & 0.280 & 2,973 & 826 & 833 \\
\hline
\end{tabular}

が，産業分類と主体別分類とはかなり対応している点も あり，結果として本稿の分析の内容の一部は，文献 (5) の主体別分析の一部に対応し，またこれを更に詳細に補 足することになる。

分析期間は Table. 1 および Fig. 1-1 以下 Fig. 1-8 までの用途別大分類の系列については 1953 年以降 1967 年までの 15 年間をとり, その他の系列については全て, 1960 年以降 1967 年までの 8 年間をとった。したがって 分散分析の $\mathrm{F}$ 值など相互に比較することはできない。

Table. 1, 2, 3 は安定的な季節変動パターンの有意性検 定のための分散分析表から，偏差平方和，F 值，などを 抜粋し，あわせて標準偏差，1964 年 1 月におけるトレン ドの值などを併記したものである（譙4）。Table. 2 の記

（注 4) 安定的な季節要素の有意性検定の分散分析について は, 文献 (3)のAppendix 它参照。なお, 原系列からトレンド と景気変動をとりのぞいた残りの系列恃季節要素 S と不規則要 素I とからなると考えられ，これを SI 要素と呼ぶ。文献 (3), (4), (5) 参照。SI 要素の特異項を調整した後, 分析期間全体に わたり，月別に平均して合計が 12.0 になるように調整したもの を安定季節要素あるいは平均的な季節要素と呼ぶ。をたここで 残楂と呼えでいるものは, このSI 要素を, 特異項調整なしの平 均的季節要素で調整した不規則变動をさし，之の分散は分散分 析における級内分散にあたる。なお，この残渣には李節变動バタ 一ソの長期的変形による影響も含まれており，単純な不規則変 動とすることはできない。本稿を通じてこの点を無視して考察 を行なっている。文献 (5) 参照。
号は Fig. 4，5 の記号に対応している。Fig. 4 は月間偏 差平方和と残渣の偏查平方和（級内偏差平方和にあた る）により各系列の位㯰づけをしたものであり，Fig. 5 は残渣の標準偏差と工事量の大きさ（トレンドの 1964 年 1 月の值で代表させた）との関係をしらべたものであ る。Fig. 1-1 以下 Fig. 1-8 までは用途別大分類の各系 列の 1953 年以降 1967 年まで 15 年間にわたる平均的季 節変動パターンであり，Fig. 1-5 および Fig. 1-6 をの ぞき分散分析の結果は有意である。Fig. 2-1-1 以下 Fig. 3-3 までは 1960 年以降 1967 年までの 8 年間にわた

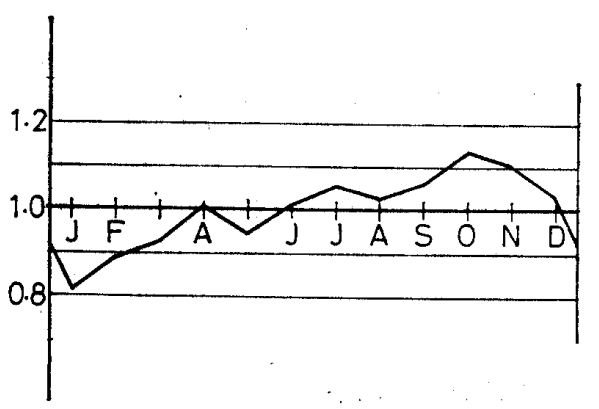

Fig. 1-1 Seasonal Fluctuation Pattern -Exclusively for dwelling居住尃用建築物 


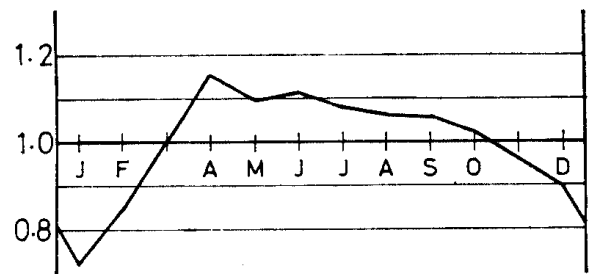

Fig. 1-2 Seasonal Fluctuation Pattern-Dwelling industry concurrent use居住産業併用建築物

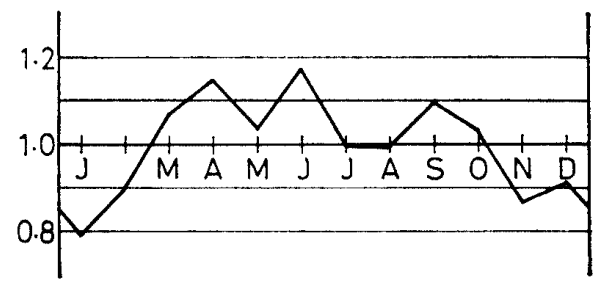

Fig. 1-3 Seasonal Fluctuation Pattern -Agricluture forestry and fishery-

農林水産業用建築物

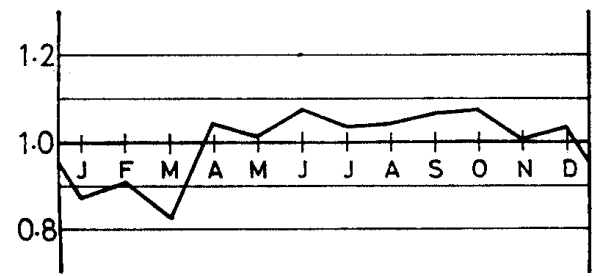

Fig. 1-4 Seasonal Fluctuation Pattern -Mining and manufactursng鈸工業用建築物

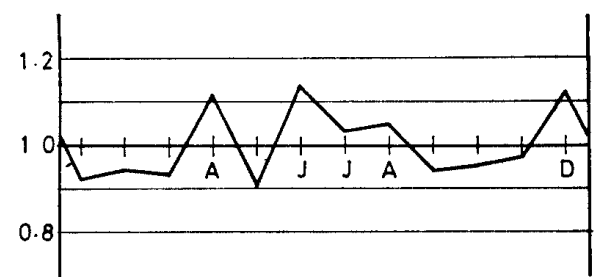

Fig. 1-5 Seasonal Fluctuation Pattern -Commercial商業用建築物

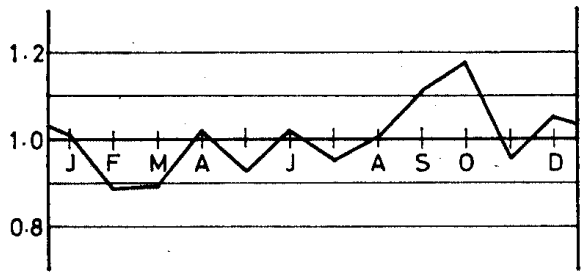

Fig. 1-6 Seasonal Fluctuation Pattern -Pubric utility-

公益事業用建築物

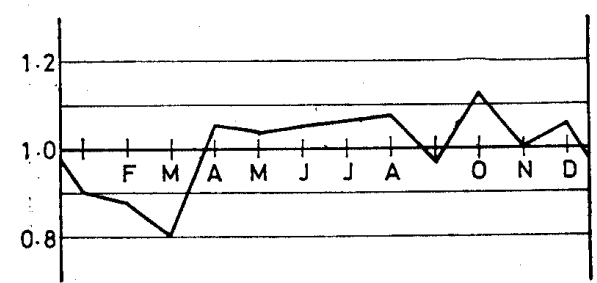

Fig. 1-1 Seasonal Flactuation Pattern -Service サービス業用建築物一

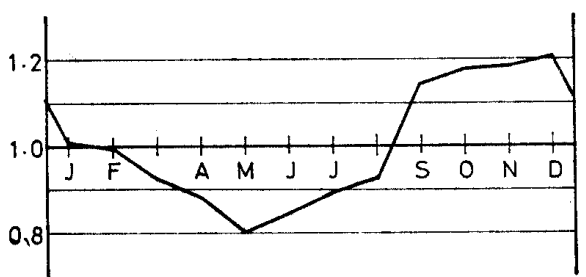

Fig. 1-8 Seasonal Fluctuation Pattern -Official and educational公務文教用建築

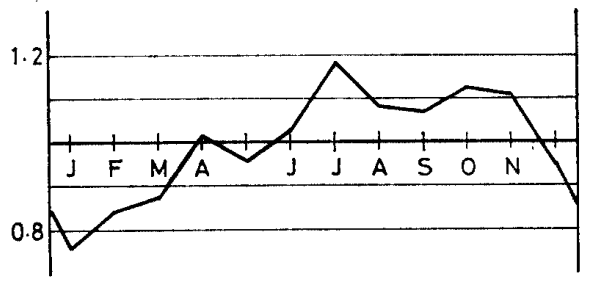

Fig. 1-9 Seasonal Fluctuation Pattern -Ordinary dwelling-

居住専用住宅

る平均的な季節变動パターンであり, Table. 2 および 3 の分類項目の5ち分散分析の結果が有意であるものであ

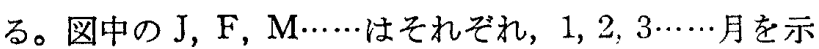
す。

\section{2. 居住用建築物の季節変動}

居住専用建築物の平均的季節変動パターンの有意性検 定における F 值は 19.57 と高く，居住産業併用建築物の F 值は 39.84 と更に 1 段と高い。ともに $\mathrm{F}_{120}^{10}(0.01)=$ 2.47 (自由度 $11 ， 168$ の代用) より大きく $1 \%$ 有意であ る (Table 1)。居住専用建築物（記号，D 簡略のため以 下 Table 1 の記号を用いる) の月間偏差平方和が 1.49 であるのに対 し，居住産業併用 $\mathrm{X}$ の月間偏差平方和が 2.58 と比較的大であるのは，それぞれの季節変動パタ ーン (Fig. 1-1，1-2) の振巾を見ても理解できる。残渣 の偏差平方和が D 1.17，X 0.99 と併用 X の值が小さ いのも F 值を相対的に高める要因となっている。残洫の 標準偏差 $\sigma_{R}$ は D 0.083，X 0.077 であり予測性も比較 的良い。Fig. 1-1，1-2 で注目をひくのは両者のパタ一 ンの対照的な相異であり，大うかかに專用は秋型，併用 は春型とすることができる。既に考察した「個人」ある いは「木造」の季節変動にみられた 4, 7, 10 月の三つの ピークが居住専用のパターンに観察されるが，全体とし ての型は秋型をとる点がやや異なる。専用 $\mathrm{D}$ は併用 X の 4 倍に近い建築量をしめすのに，季節変動杜相対的に 不安定であり，また秋型ないし年末型をとるのは公営・ 公団住宅の影響によるものであると想像される。

Table 2 の用途別中間分類によれば，居住専用建築物 D の内訳は居住専用住宅 D 1 と居住専用準住宅 D 2 の 二者であり，併用建築物 X の 内訳は 産業分類にしたが 、，農林水産業併用 X 1 ，鉱工業併用 X 2 , 商業併用 


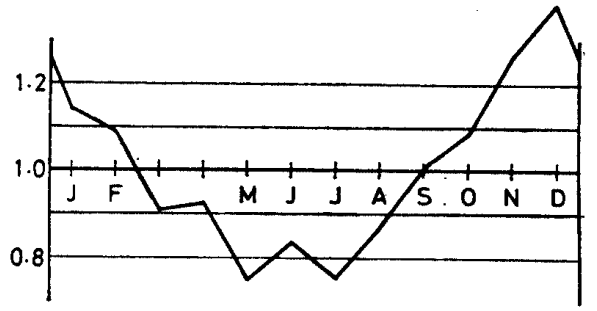

Fig. 2-1-2 Seasonal Fluctuation Pattern -Quasidwelling-

居住尃用準住宅

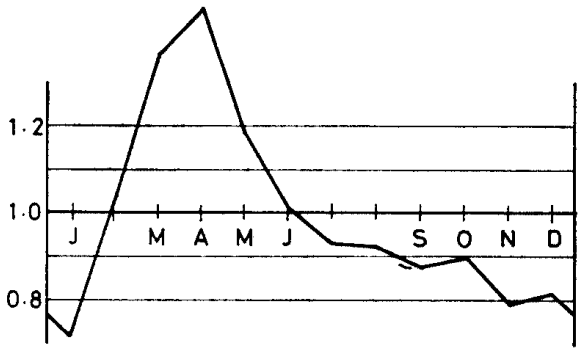

Fig. 2-2-1 Seasonal Fluctuation Pattern -Dwelling, and agriculture, forestry or fishery居住農林水産業併用

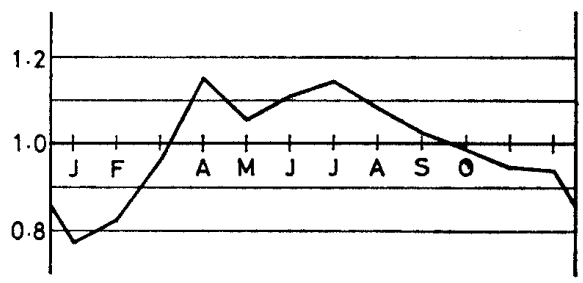

Fig. 2-2-2 Seasonal Fluctuation Pattern -Dwelling, and mining or manufacturing 居住鉱工業併用

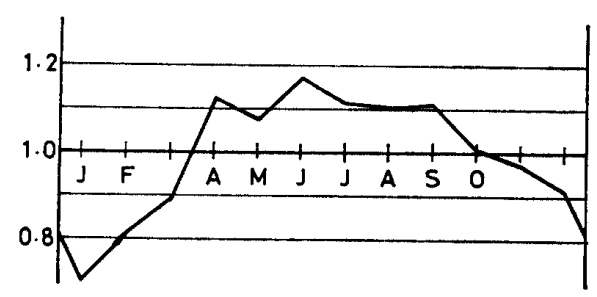

Fig. 2-2-3 Seasonal Fluctuation Pattern -Dwelling and commercial居住産業併用

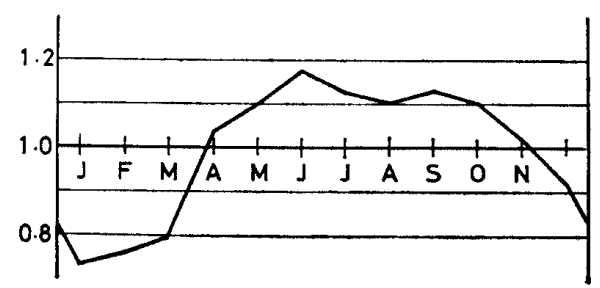

Fig. 2-2-4 Seasonal Fludtuation Pattern -Dwelling and service居住サービス業併用

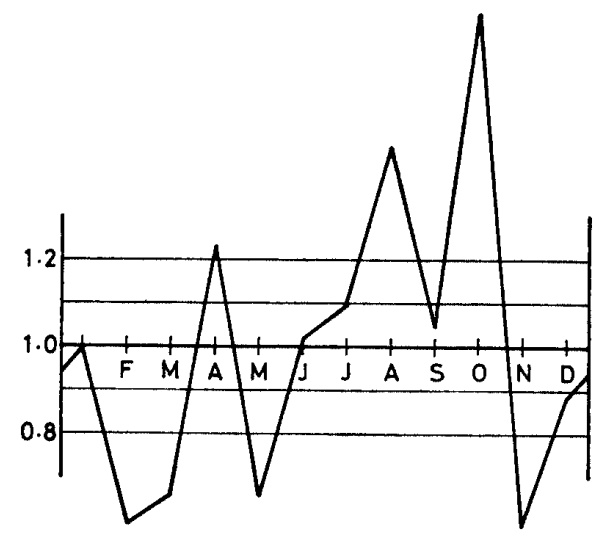

Fig. 2-4-1 Seasonal Fluctuation Pattern -Coal mining-

石炭鉱業用

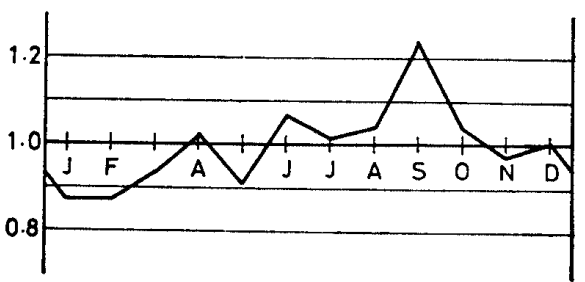

Fig. 2-4-2 Seasonal Fluctation Pattern -Lumber and wood products-

木製品製造業用

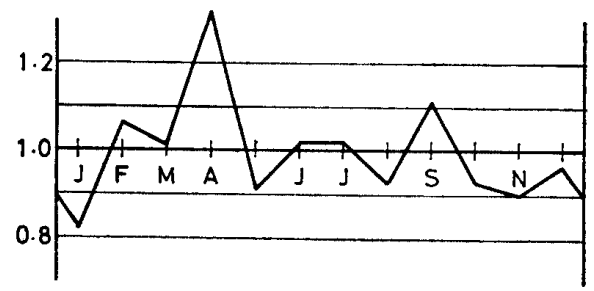

Fig. 2-4-3 Seasonal Fluctuation Pattern -Chemical and related industries化学工業用

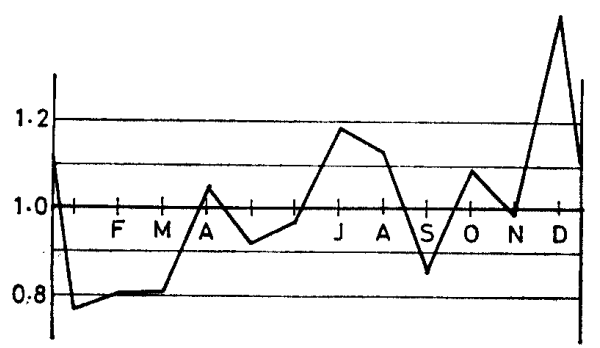

Fg. 2-4-4 Seasonal Fluctuation Pattern -Stone clay, glass and pottery products割業土石製品製造業

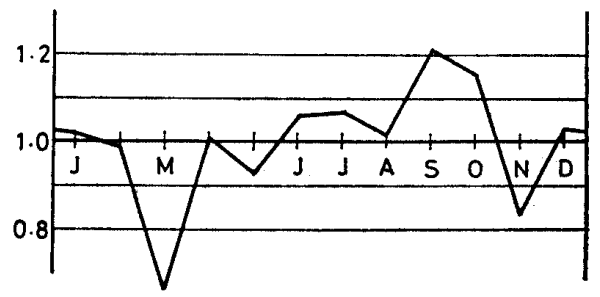

Fig. 2-4-5 Seasonal Fluctuation Pattern -Iron and steel industry-

鉄 鋼 業 用 


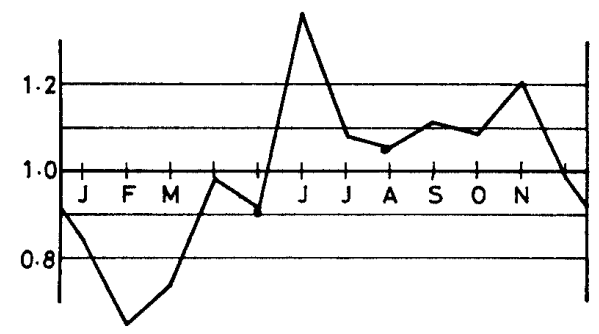

-Fig. 2-5-1 Seasonal Fluctuation Pattern -Restaurant飲 食 店 用

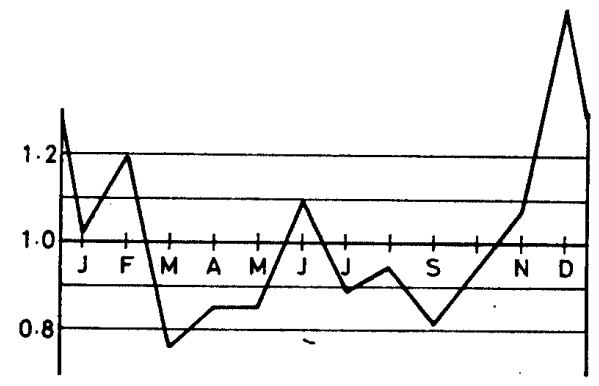

Fig. 2-5-2 Seasonal Fluctuation Pattern -Finance insuramce and real estate金融, 保険業, 不動産業用

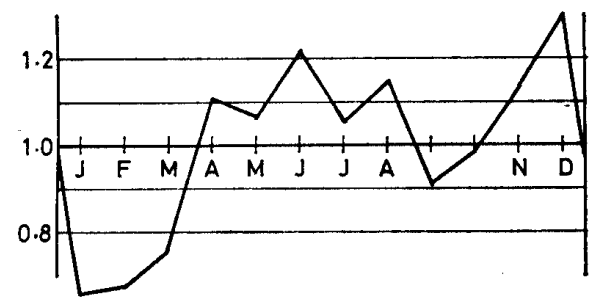

Fig. 2-7-1 Seasonal Fluctuation Pattern -Hotels and other lodging宿 泊 業 用

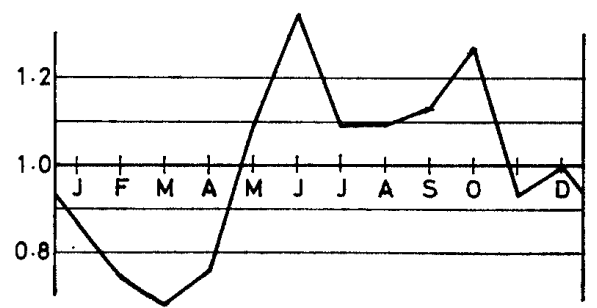

Fig. 2-7-2 Seasonal Fluctuation Pattern -Amusement and recreation services-

娛 楽 業 用

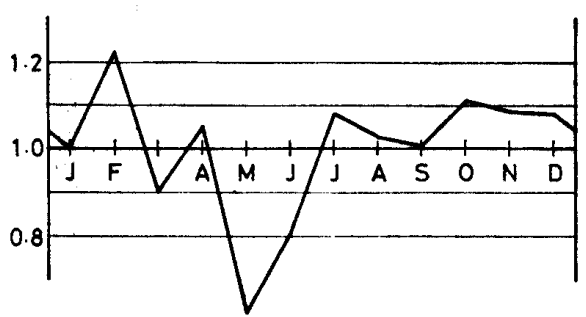

Fig. 2-8-1 Seasonol Fluctuation Pattern -Government公 務 用

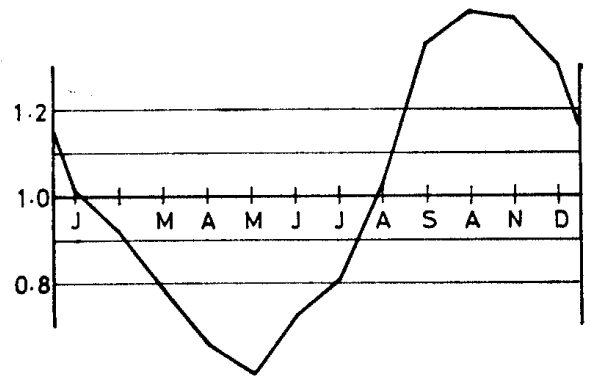

Fig. 2-8-2 Seasonal Fluctuation Pattern -Education文 教 用

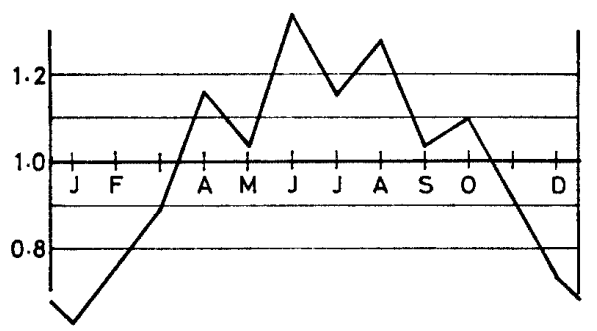

Fig. 2-8-3 Seasonal Fluctuation Pattern -Religion宗 教 用

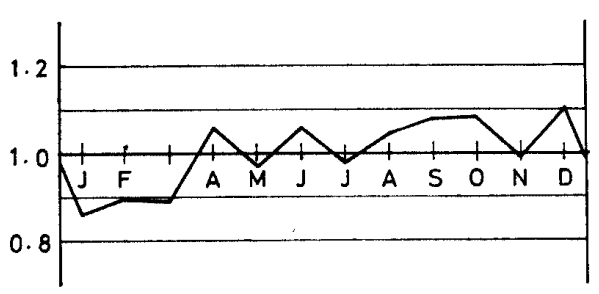

Fig. 3-1 Seasonal Fluctuation Pattern -Factory工場及び作業場

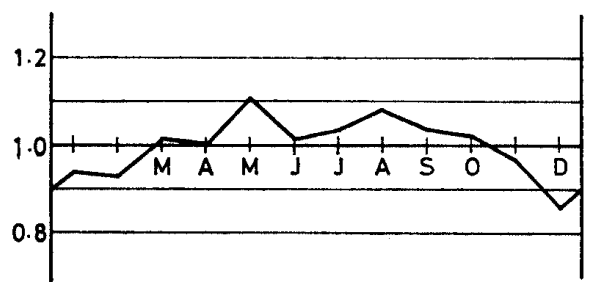

Fig. 3-2 Seasonal Fluctuation Pattern-Warehouse-

倉庫

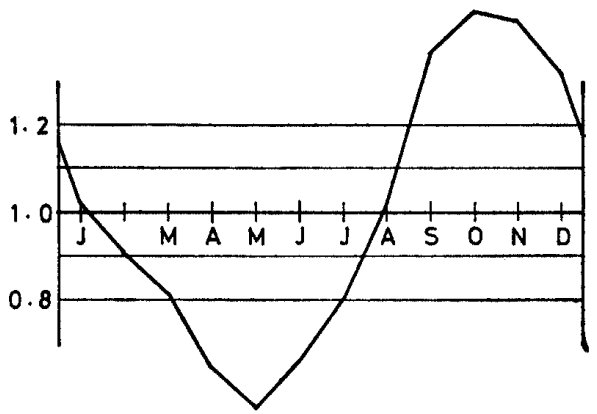

Fig. 3-3 Seasonal Fluctuation Pattern -School学校の校舎 
$\mathrm{X} 3$ ，サービス業併用 X 4, その他併用 (省略) である。 これら居住関倸の建築物供共通する特色は $\mathrm{F}$ 值の高いこ とであり, Table 2 の他の分類項目と比較しても群を抜 いて高水準にある。居住関倸以外でこれほぞ顕著な季節 変動を示すのは農林水産業用と文教用だけである。

農林水産業併用 X 1 の F 值が 48.74 で一番高く, 以 下商業併用 X 3 , 専用住宅 D 1, 集住宅 D 2, サービス 業併用 X 4, 鉱工業併用 X 2 の順に低くなる。残渣の標 準偏差 $\sigma_{R}$ は，X 3 が 0.074 で最小であり, 以下 $\mathrm{D} 1$, $\mathrm{X} 1 ， \mathrm{X} 2$ の順に高くなるが，いずれも最低水準のグル 一プに属する。Fig. 5 によれば，居住関係の $\sigma_{R}$ は単に 低水準にあるだけでなく，A 線からかなりはなれてい る。居住専用 D 1 だけはその例外で $\mathrm{A}$ 線の近くにあり， この $S_{R}$ 值はその絶対額相応の值であると考えられる が，他の $\sigma_{R}$ 值は絶対額の割に小さく，予測性が良い。 月間偏差平方和は X 1，D 2, X 3，D 1 の順であるが， その值は平均的水準にある。居住関倸の $\mathrm{F}$ 值が高いのは 主として, 残渣の偏差平方和が小さいことによるもので ある(Fig. 4 参照)。

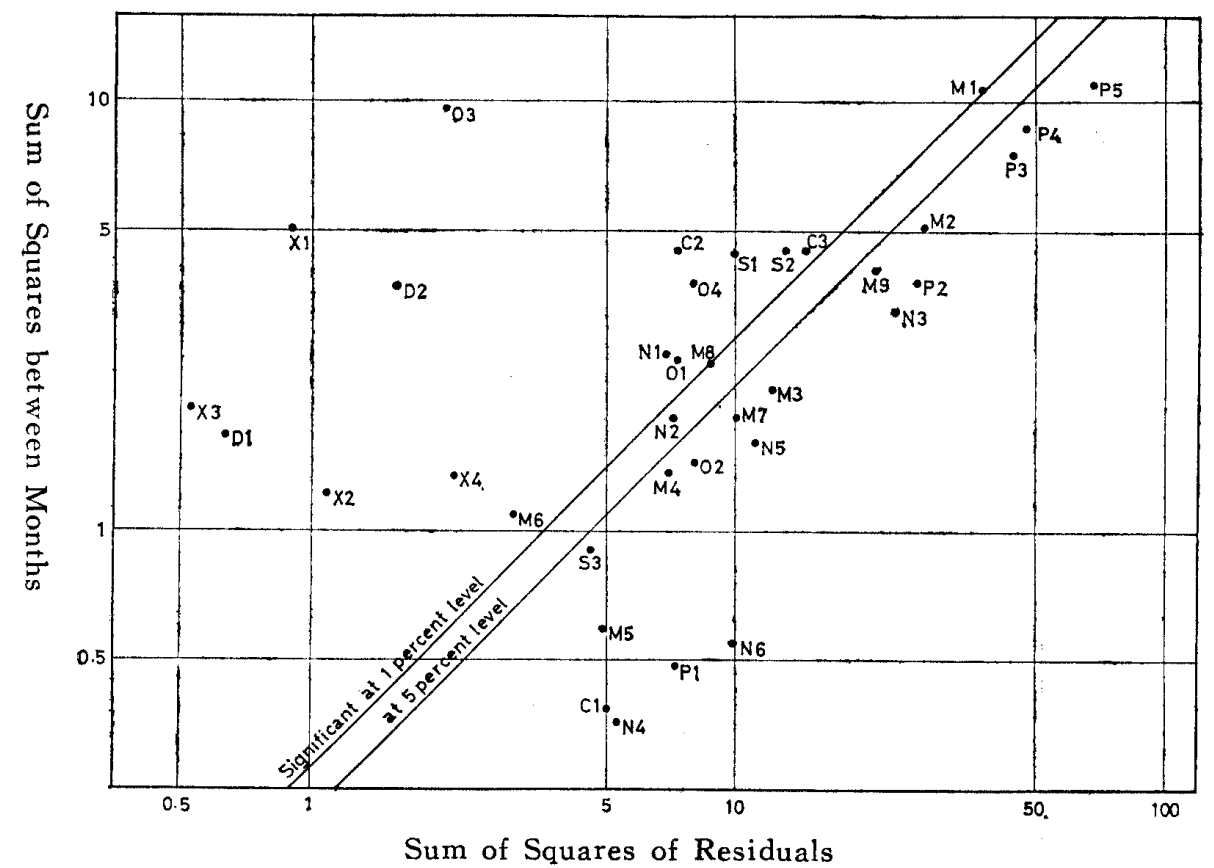

Fig. 4 Sum of squares between months and sum of squares of residuals of each intermediate group of building starts by use and by industries

Fig. 2-1-1 から Fig. 2-2-4 までに, 各系列の季節変 動パターンを示す。専用住宅が，居住専用 (Fig. 1-1) に似た夏秋型であるのに対し，居住専用準住宅は他に例 をみない典型的な冬型であり, 12 月の高いピークを中心 にして 11 月〜2月が高く，夏期は低水準になる。併用住 宅では農林水産業併用 (Fig. 2-2-1) が顕著なパターン をとっており，4月のピークを中心として $3 \sim 5$ 月に集 中している。振巾も大きく, 最高の 4 月は最低の 1 月の 2 倍に及ぶ。Fig. 1-2 の居住産業併用建築物のパターン が春型となっている要因の主力がこの農村水産業併用住
宅にあることがわかる。鉱工業併用，商業併用，サービ ス業併用の三者は相互に似たパターンをしめし，特色の ない夏型となっている。鉱工業併用は 4 月から 8 月，商 業併用は 4 月から 9 月, サービス業併用は 5 月から 10 月にかけてゆるやかな山があり，その位置は互、に少し ずれている。鉱工業併用と商業併用に共通の 4 月のピー ク，商業併用とサービス業併用に共通の 6 月と 9 月のピ ークなどが観察できる。注目すべきことはこの三者がそ れぞれ対応する鈗工業用，商業用，サービス業用（Fig. 1-4，1-5，1-7）と比較しても㐫まり類似点がみられない ことである。商業用建筑物 (Fig. 1-5) はF值が 1.46 と 低く，パターン自体が有意でないから論外としても，他 二組の間にも，冬期に水淮が低下するといらこと以外は 類似点が見出されない。農林水産業用之農林水産業併用 の間にも類似点が見られないことと符号して抢り，併用 住宅といらものの性格の一面を伺らことができる。

\section{3. 建物種䅡別の季節变動}

住居関係以外の建物種類別各系列の $\mathrm{F}$ 值は Table. 3 のとおり学校の校舎をのぞき全般に低い。 $F_{84}^{11}(0.01)=$ 2.42 をこえるのは，学校の校 舎 37.63 , 工場および作業場 4.21 ，倉庫 2.43 の三者であり， そのパターンは Fig. 3-1 から Fig. 3-3 までのとおりである。 学校校舎は既に考察した主体別 の地方自治体に対応しており， また本稿 Fig. 2-8-2 の文教用 にはほとんど完全に一致してい る。工場および作業場のパター ンはあまり顕著でなく, 1 3 月 が低く他の月がやや高い。Fig. 1-4 の鉱工業用のパターンに似 ているが当然である。倉庫は F 值が $1 \%$ 有意ぎりぎりの 2.43 であり，パターンの細部の信賴 性は低い。5月にピークが来て いるのが他には見られない特色 である。概して建物種類別は居 住関係と学校の校舎についてはきわめて明膫な季節周期 性をきわだたせるが，その他の建物についてはあまり有 効な分類ではなさそうである。

\section{4. 鉣工業用建築物の季節変動}

鉱工業用建築物の F 值は 6.41 で $1 \%$ 有意であるが， そのパターン (Fig. 1-4) はあまり顕著ではない。1 3 月の冬期に低くなるだけで，きわだったピークもない。 月間偏差平方和は 1.00 で Table. 1 の用途別大分類の中 で最小である。残渣の偏差平方和が 2.38 で比較的小さ いため, F 值が商業用あるい怡公益事業よりも高くなっ 
ているのである。したがって Total の偏差平方 和も住居関倸纪次ぐ小さい值で，季節要素，不規 則要素を含めて短期変動の小さいことがわかる。 鉱工業用の絶対額は 居住專用 $\mathrm{D}$ に次ぐ第 2 位の 大きさであり, 件数も多くランダムな要素が相互 に消しあっていることが予想されるが，絶対額の 短期変動の標準值 $\sigma_{T} \mathrm{~A}$ では, 商業用, 公務文教 よりも小さく第 4 位であり，季節要素をのぞいた $\sigma_{R} \mathrm{~A}$ でも第 3 位で， 2 位の商業用を大きく下ま わっている(圾 5)。鉱工業用建築物が景気変動に 敏感に反応することは周知のことであるが，その 合計額においてみるかぎり鉱工業建築物は比較的 おとなしい短期変動をするといえそうである。

鉣工業用の内訳は Table. 2 の中間分類 15 種 のほか, その他製造業, その他鈗工業の 2 者 （省略）がある。表にみるとおりいずれも季節変 動は明確でない。石炭工業用，木製品製造業用，

窯業土石製品製造業用の 4 者の $\mathrm{F}$ 值が $\mathrm{F}_{84}^{11}(0.01)=2.42$ を上まわり，鉄鋼業用の $\mathrm{F}$ 值が $\mathrm{F}_{84}^{11}(0.05)=1.91$ を上ま わって $5 \%$ 有意である。そのパターン (Fig. 2-4-1 Fig. 2-4-5）は様々で互いに類似点が少ないばかりでなく， 鉱工業合計のパターン (Fig. 1-4) との共通点もなく， 1 3 月が低いといらことさえ共通でない。

本稿で採用した産業分類の中間分類では，鈗工業用の 内訳をこまかくわけすぎたきらいがあり，全体にランダ ムな要素が強く影響して各系列の $\mathrm{F}$ 値が小さくなってい ると考えられるが，石炭鈗業用，木製品製造業用，筀業 土石製品製造業など絶対額の小さいもので有意性を示す ものがあるので，内訳をしらべた意味が全くないわけで はない。Fig. 4 にみるとおり鉱工業用中間分類の大半は $5 \%$ 有意水準の限界線のやや下部に沿って分散してお り, 残渣の偏差平方和が大きくなるにしたがい月間偏差 平方和が大きくなるようにみえるが，これは分析期間が 短かく分類をこまかくしすぎたために大きなランダム変 動が平均的な季節要素に混入し, その結果月間偏差平方 和が見かけ上大きくなっている疑いがこく，あまり意味 がない。むしろ，これらのグループはランダム要因につ いては共通の性格をもつ1グループを形成していると考 えるべきだろう。このグループに入らないのはすでにの べた季節変動が有意な系列のほか，月間偏差平方和がず っと低水準汇ある繊維工業 M 5 ，金属製品製造業 $\mathrm{N} 4$, 輸送用機械器具 N 6 であり,この三者については季節性 はないといえそうである。その他の系列については，分

（註 5）各系列はいずれも急速な增加トレンドを含えでおり， 固有な絶対量というものを規定できない。ここでは簡単な比較 ができれば十分なので, 任意にほぼ中央の 1964 年 1 月のトレン ドの值を各系列の便宜的な絶対量として符号 A であらわしてい

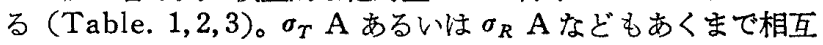
の比較のためだけのもので時系列的には意味のない数值である。

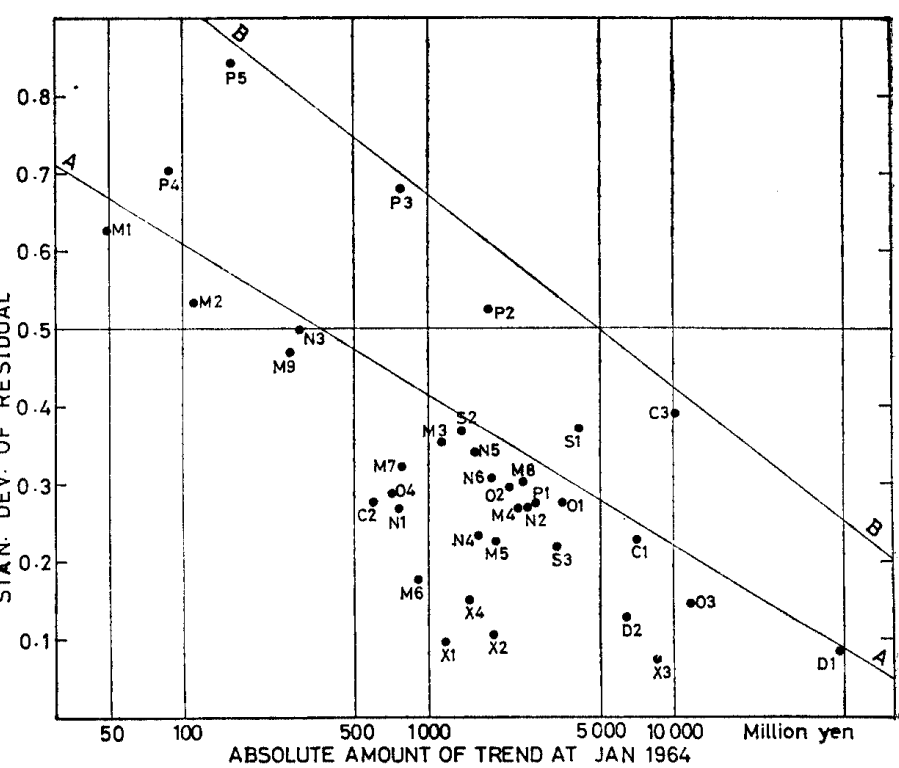

Fig. 5 Standard deviation of residuals and the absolute amount of trend at Jan 1964 of each intermediate group of building starts by use and by industries 析期間を長くとったり，相互に加えた系列でみたり，あ るいは季節変動パターンの推移を考慮することにより， 有意な季節変動パターンがみいだせる可能性は十分にあ る。

Fig. 5 は各系列の絶対量 $\mathrm{A}$ と残渣の 標準偏差 $\sigma_{R}$ と の関係をプロットしたものである。建築量が大きくなる ほど（平均規模に大きな変化がなく，主として件数の増 加によるものとすれば）ランダムな要素が互いに消しあ うから $\sigma_{R}$ が小さくなることが予想され，事実その逆相 関は明瞭である。A 線の位置に壁のようなものが観察 され，点の大部分は $\mathrm{A}$ 線の下部に分散して $\mathrm{A}$ 線をこえ るものは公益事業関係の 4 種, 通信 P 2, 電気 P 3, ガ ス $\mathrm{P} 4$, 水道 P 5 のほか, 宿泊業用 S 1, 金融保険業不 動産業用 C 3 だけである。鉱工業用は全て A 線の下に 位置し，かなり良い逆相関を示している。 $\mathrm{A}$ と $\sigma_{R}$ との 関係においても，鉱工業用の大半のものはひとつの均一 なグループを形成しているのであり，この逆相関からは ずれる $\mathrm{N} 1, \mathrm{~N} 4, \mathrm{M} 5, \mathrm{M} 6, \mathrm{M} 7$ のちち, N 1, M 6 は季節性有意とされたものであり，N 4, M 5 汢季節変 動なしとされたものである。かくて鉣工業用建築物の内 訳の諸系列のうち大半がその絶対額に応じてランダム要 素の大きさが決まり，またその大半が，そのランダム要 素により季節周期性が不明確になっているといらことに なる。

\section{5. その他の産業用建築物の季節䘫動}

Table. 1 の用途別大分類の諸系列らち, 商業用と公益 事業用は $\mathrm{F}$ 值が低く，その季節変動パターンは（Fig. 1-5，1-6）有意でない。サービス業用の F 值は 3.49 で 有意ではあるが，そのパターンの信頼度は低い。鉱工業 用のパターンに似ていることが気付かれるが，おそらく 深い意味はないだろら。公務文教用は 11.67 とかなり高 
いF 值を示すが，そのパターンはすでに主体別分析で考 察した年末型である。

産業別中間分類で以上の内訳をみるとその安定度，パ ターンは様々である。まず公益事業関係の 5 系列の $\mathrm{F}$ 值 が全て 1.91 以下で有意性のないのが目立つ。Fig. 5 に よれば P 1 を除き P 2 P 5 は全て A 線の上に出る特 殊グループであり，その絶対量の大きさの割に不安定度 が強い。また $\sigma_{R}$ の大きさも Table. 2 のトップグルー プを占めており，公益事業関係は運輸業用をのぞき，1 グループを形成しているといえ，その特性は極端に大き な不規則変動である。

商業用建築物の内訳は卸小売業用 C 1 , 飲食店用 C 2 , 金融保険業不動産業用C 3 である。卸小壳業は絶対額が かなり大きく，その不規則要素は比較的小さいにもかか わらず，月間偏差平方和は 0.38 で最低水準に 属 L, F 值が 0.68 と低い。単に有意性がないだけでなく，季節 周期性そのものがほとんどないらしい。運輸業に似た性 格をもつといえよう。全体としての商業用建築物は有意 性なしであったが，その内訳の 飲食店用 C 2 の F 值は 5.36 金融保険業不動産業 C 3 は 2.68 で共に有意であ る。月間偏差平方和は同水準にあるが，残渣の偏差平方 和は C 2 の方が小さい。 $\sigma_{R}$ の值は C 2 が 0.28 , C 3 が 0.39 で C 1 の 0.23 上り高い。C 1 の季節変動は有意で ないが，短期変動の振巾は一番小さい。サービス業内訳 では，宿泊業用，娛楽業用の二者が有意で，医療業用は 月間偏差平方和が 小さく， $\sigma_{R}$ の值が小さいにもかかわ らず，有意性なしである。

季節変動が 有意なものの パターンは Fig. 2-5-1 以下 Fig. 2-7-2 までのとおりであり，他の系列にはみられな い特異な型をしている点が注目される。飲食店用と娛楽 業用のパターンがよく似ており，また金融保険業不動産 業用と宿泊業用に共通の 12 月の特異なピークがみられ る。

公務文教用は非営利団体用以外は有意で，そのパター ン (Fig. 2-8-1，2-8-2，2-8-3) は各々特色をもつ。公
務用は年度始めの 5,6 月が低く, 2 月にピークがあって 年度末型であるが，文教用ほどの明確な山もなく，その $\mathrm{F}$ 值むはるか低い。文教用は F 值が 40.12 できわめ て影著な季節周期性を示し，パターンは年末型である。 宗教用は F 值が 4.12 でパターンは夏型であるといえよ う。全体としての公務文教用の季節変動は，主として文 教用によって支配されている。

\section{6.むすび}

既に試みた主体別分析あるいは構造別分析に比較し て，本稿の用途別分析は建物種別㧍よび産業中間分類別 のこまかいグループに分けることができるので，今まで 以上に詳細に各系列の特性をしらべることができた。着 工統計は全体にランダムな要素が強く支配しており，季 節変動が不規則変動の中にかくれてしまう傾向がある。 この傾向は分類をこまかくするほど強くなるので，着工 予定額の季節変動の研究には，ひとつの限界のようなも のがあるといえよう。しかし，本稿の分析はこのテーマ にかんする一次的な接近にすぎず，更に様々な試みが続 けられねばならないことはいうまでもない。

本稿の分析で必要とした計算は全て, 東京大学大型計 算機センターを利用した。

\section{[参 考文 献]}

文献（1） 内山諫，建築統計の現状と問題点，建築䧱誌 1968.2 pp 109

文献 (2) 建設省計画局調査統計課, 建築投資推計一一推計方 法と問題点, 建設経済月報 1967.9 pp 4

文献 (3) U.S. Dept. of Commerce, Bureau of the Census, The X-11 Variant of the Censos Method II, Seasonal Adiustment Program, (Tecnnical Paper No. 15) U.S. Dept. of Commerce, Bureau of the Census, U.S.A. Feb. 1967

文献（4）日本銀行統計局 経済観測基檚統計センサス局法 IIX 11 による季節調整 昭和 42 年 4 月

文献（5） 島田良一 建築主別建築工事費着工予定額の季節変 動について, 日本建築学会論文報告集 第 152 号 昭和 43 年 10 月

文献（6）島田良一 構造別の建築工事費着工予定額の短期変 動について 日本建築学会論文報告集 第 157 号 昭和 44 年 13 月 
these method are not always useful to design every architecture, rather should be limited to the design of architecture described the inner functions clearly i. e. school or hospital building.

In order to generalize these methods, there remain some problems how to make the briefs logical and to arrange them to be able to operate, or how to make the decision in a design process logical.

U.D.C. $72.011 .1: 721$

\section{TIME STUDIES ON USERS OF URBAN FACILITIES (Part 3.)}

by Dr. KOHSEI OKADA, Prof. Osaka Univ., KATSUYUKI YOSHIDA, Assist, Osaka Univ., SHIRO KASHIHARA, Assist, Osaka Univ. Member of A.I.J.

In this paper, we report such results of time studies about theaters, auditoriums, baseball grounds, examination halls, factories as follows;

1 On the audience who arrive at theaters or halls, modes of concentration curves are between 5 and $10 \mathrm{~min}$. before the time when the curtains rise, and ratio of concentration in $5 \mathrm{~min}$., is about $15 \%$.

2 On the spectators who arrive at baseball ground, modes of concentration curves are between 10 and 20 min. befoe play ball time, and ratio of concentration in 5 min., is about $13 \%$.

3 On the persons who arrive at examination halls, modes of concentration cirves are between 25 and 35 min. before biginning time of examination, and ratio of concentration in $5 \mathrm{~min}$. is about $15 \%$.

4 On the persons who leave examination halls, modes of concentration curves are between 0 and $10 \mathrm{~min}$. after the end time of examinations, and ratio of concentration in $5 \mathrm{~min}$. is about $45 \%$.

5 On the persons who leave factories, modes of concentration curves are between 20 and 25 min. behind the end time of works, and ratio of concentration in $5 \mathrm{~min}$. is about $14 \%$.

U.D.C. 725.51 .011 .1

LOCATION AND SIZE OF THE RADIOLOGY.

Depatment-Studies in the Functions

anb Design of Hospitals.

by Dr. MAKoTo ITO, Associatie Prof. of Chiba Univ., Member of A.I.J.

This paper describes the investigation of the use of radiology department in general hospital to determine the location and size of it. The results of analysis are as follows:

1) The proportion of use between diagnostic $X$-ray and radiological therapy is $80 / 20$. The relative importance of the latter is increasing year by year.

2) About 30 40 per cent of total use is held by in-patients. As for the diagnostic X-ray use only, the proportion of in-patients is no more than $20 \sim 30$ per cent.

3) The proportion of the internal medicine is the best out of O.P.D. and the orthopedics is next.

4) The greater part of therapeutic radiology is held by in-patients.

5) In community general hospital, the number of patients using diagnostic radiology is $3 \sim 4$ a day per 100 beds and $6 \sim 7$ per 100 out-patients. Concerning the radiological therapy, the number of patients is 2.0 a day per 100 beds and 0.5 per 100 out-patients.

U.D.C. 60.003 .12

\section{STUDY ON THE SHORT-TERM FLUCTUATION OF THE BUILDING STARTS BY USE AND INDUSTRIES IN JAPAN}

Mainly on the Seasonal Fluctuation-

by RYOICHI SHIMADA Assistant, Tokyo Metropolitan University, Member of A.I.J.

This is the third study on the seasonal and irregular fluctuation of the building starts in Japan. By table $1,2,3$ we can know the significance of the seasonal fluctuation pattern and the scale of seasonal and irregular factors. As each series has a trend, the value of trend at Jan. 1964 is selected for the comparison of the absolute amount of each series. For the $F$-test of meaningful seasonality, the $F$ value of Table 1 is compared with $F_{120}^{10}(0.01)=2.47$ (instead of $F_{18 \mathrm{~B}}^{11}(0.01)$ and the $F$ value of Table 2 and 3 is compared with $F_{84}^{11}(0.01)=2.42$ or $F_{84}^{11}(0.05)=1.91$ The seasonal fluctuation patterns of building starts by major group are shown in Fig. 1-1 Fig. 1-8. Only the significant seasonal patterns of the series in Table 2 and 3 are shown in Fig. 2-1-1 Fig. 3-3.

Series related with dwellings have high $F$ values and each series has an unique seasonal pattern. Building for Agriculture, Forestry and Fishery and Educational Buildings also have high $F$ values. Some of the other series have weak seasonality and some does not have at all, as shown in tables and figures. 
In order to know the details of the seasonal fluctuation of building starts, we must classify them into many small groups. However, small group usually has strong irregular fluctuation and this gives a difficulty for finding the meaningful seasonalyity patterns.

U.D.C. $72.03: 725.171$

THE USE OF TO-SANJO-DONO PALACE AT THE TAIKYO FESTIVAL.

-Part. 1.-

by Dr. SEIROKU OTA, Prof. of Kyu-syu Univ. Member of A.I.J.

This study is how to make use of the aristcratic palace Tosanjo-dono, so-called Shindenzuknri, at Heian Period, about 1150 years ago. 